\title{
TINJAUAN PERHITUNGAN DAN PEMOTONGAN PPh PASAL 21 PADA CV SAGA RETAILINDO SORONG
}

\author{
Markus Muda, SE \\ Jurusan Akuntansi Keuangan Publik \\ Program Studi Sarjana Terapan Akuntansi Keuangan Publik \\ Politeknik Katolik Saint Paul Sorong \\ Email: markusmuda@gmail.com
}

\begin{abstract}
ABSTRAK
Pajak adalah kontribusi wajib kepada negara yang terutang oleh orang pribadi atau badan yang bersifat memaksa berdasarkan Undang-Undang, dengan tidak mendapatkan imbalan secara langsung dan digunakan untuk keperluan negara bagi sebesar-besarnya kemakmuran rakyat. Salah satu jenis pajak yang memberikan kontribusi terhadap penerimaan pajak adalah pajak penghasilan (PPh) yang diperoleh dari penghasilan wajib pajak orang pribadi, badan dan bentuk usaha tetap (BUT). Penelitian ini dilakukan pada CV Saga Retailindo Sorong. Tujuan dari penelitian ini adalah untuk mengetahui apakah perhitungan dan pemotongan Pajak Penghasilan Pasal 21 yang dilakukan CV Saga Retailindo Sorong telah mengacu pada Peraturan Perpajakan yang berlaku di Indonesia. Latar belakang penelitian ini adalah bahwa pemotongan Pajak Penghasilan Pasal 21 akan mengurangi penghasilan yang diterima karyawan CV Saga Retailindo Sorong. Metode analisis yang digunakan dalam penelitian ini adalah metode kualitatif dan kuantitatif. Dalam penelitian ini penulis menguji dan membandingkan antara perhitungan Pajak Penghasilan Pasal 21 yang telah dilakukan perusahaan apakah telah sesuai dengan Peraturan Perpajakan yang berlaku. Berdasarkan hasil penelitian perhitungan dan pemotongan Pajak Penghasilan Pasal 21 yang telah dilakukan oleh perusahaan belum mengacu pada peraturan perpajakan yang berlaku pada tahun 2014 dan 2015. Dalam melakukan perhitungan biaya jabatan perusahaan belum mengacu pada PER-32/PJ/2015 Pasal 10 ayat (3) a. Penerapan untuk kedepannya disarankan perusahaan benar-benar menerapkan peraturan perpajakan yang berlaku dan meningkatkan kepatuhan terhadap peraturan perpajakan dan terus memperhatikan informasi terbaru yang berkaitan dengan perubahan-perubahan yang diberlakukan oleh Menteri Keuangan maupun Direktorat Jenderal Pajak guna menghindari masalah serta pelanggaran-pelanggaran.
\end{abstract}

Kata kunci: Perhitungan dan Pemotongan PPh Pasal 21

\begin{abstract}
Tax is a compulsory contribution to state tax owed by persons or entities that are forced by laws, to not get rewarded directly and used for the purposes of the state. - the amount for the welfare of the people. One of the types of taxes that contribute to the tax revenue is income tax (VAT), which is obtained from a private person on this income taxpayers, entities and permanent establishments. This research was conducted at CV Saga Retailindo Sorong. The purpose of this study was to determine whether the calculation and withholding tax article 21 carried by CV Saga Retailindo Sorong have been referring to the existing tax regulations in Indonesia. The background of this study is that cutting the income tax-article 21 will reduce the income received by employee in $C V$ Saga Retailindo Sorong. The analytical method used in this study is a qualitative and quantitative methods. In this study the authors examine and compare between the calculation of income tax article 21 which had been done by the company whether in accordance with the tax regulations. Based on the research result and the calculation of withholding tax article 21 have been carried out by the company had not referred yet to the prevailing taxation rule in 2014 and 2015. In the calculation the cost of corporate positions do not refer to PER-32/PJ/2015 article 10 clause (3) a. Implementation of the suggested future companies actually implement tax regulations and improve compliance with tax regulations and continue to pay attention to the latest information relating to the regulations imposed by the finance minister and the directorate general of taxation in order to avoid the problem of the problem as well as misdemeanor violation.
\end{abstract}

Keywords: Calculation and Withholding Tax-Article 21 


\section{Pendahuluan}

\subsection{Latar Belakang}

Salah satu sumber penerimaan negara yang digunakan untuk membiayai pembangunan di Indonesia yang berlangsung secara terus menerus dan berkesinambungan yang bertujuan untuk meningkatkan kesejahteraan masyarakat adalah bersumber dari penerimaan pajak. Pentingnya pemahaman wajib pajak tentang kesadaran membayar pajak sangat diperlukan untuk meningkatkan penerimaan pendapatan negara dari sektor pajak. Pajak menurut Pasal 1 ayat 1 UndangUndang No. 6 Tahun 1983 sebagaimana telah disempurnakan terakhir dengan UndangUndang No. 16 Tahun 2009 tentang Ketentuan Umum dan Tata Cara Perpajakan adalah kontribusi wajib kepada negara yang terutang oleh orang pribadi atau badan yang bersifat memaksa berdasarkan Undang-Undang, dengan tidak mendapatkan imbalan secara langsung dan digunakan untuk keperluan negara bagi sebesar-besarnya kemakmuran rakyat. Salah satu jenis pajak yang memberikan kontribusi terhadap penerimaan pajak adalah pajak penghasilan $(\mathrm{PPh})$ yang diperoleh dari penghasilan wajib pajak orang pribadi, badan dan bentuk usaha tetap (BUT). Perusahaan sebagai wajib pajak badan/ pemberi kerja wajib untuk melakukan pemotongan PPh Pasal 21 atas penghasilan yang diperoleh dari pekerjaan, jasa, atau kegiatan dengan nama dan dalam bentuk apapun yang diterima wajib pajak orang pribadi dalam negeri. Kewajiban perusahaan untuk memotong pajak karyawan harus sesuai dengan Undang-Undang dan peraturan yang berlaku sehingga pajak yang dipotong perusahaan bagi karyawan tidak terlalu besar dan tidak terlalu kecil yang akan mempengaruhi take home pay karyawan. Sebagai pemberi kerja CV Saga Retailindo Sorong diwajibkan untuk melakukan perhitungan, pemotongan, penyetoran dan pelaporan atas penghasilan karyawan sesuai dengan ketentuan dalam Undang-Undang Pajak Penghasilan Pasal 21 yang berlaku yaitu Undang-Undang No. 36 tahun 2008 dan Peraturan Menteri Keuangan No.122/PMK.010/2015. Berdasarkan uraian diatas penulis tertarik untuk menulis tentang bagaimana perusahaan melakukan perhitungan untuk menetapkan besarnya pajak penghasilan karyawan yang harus dipotong yang akan mempengaruhi take home pay karyawan berdasarkan peraturan perpajakan maka penulis mengambil judul: "TINJAUAN PERHITUNGAN DAN PEMOTONGAN PPh PASAL 21 PADA CV SAGA RETAILINDO SORONG".

\subsection{Rumusan Masalah}

Berdasarkan latar belakang di atas, maka rumusan masalah yang penulis kemukakan yaitu:

1. Bagaimana proses perhitungan dan pemotongan PPh Pasal 21 karyawan?

2. Berapa take home pay karyawan yang menerima tunjangan dan yang tidak menerima tunjangan?

3. Apakah jumlah pemotongan PPh Pasal 21 karyawan sudah sesuai dengan UndangUndang PPh No. 36 tahun 2008?

\subsection{Batasan Masalah}

Dalam penelitian ini, penulis membatasi pembahasan hanya pada metode perhitungan dan pemotongan PPh Pasal 21 yang ditanggung oleh karyawan CV Saga Retailindo Sorong tahun 2014 dan tahun 2015.

\subsection{Tujuan dan Manfaat Penelitian}

1.4.1 Tujuan Penelitian

Adapun tujuan penelitian ini adalah:

1. Untuk mengetahui proses perhitungan dan pemotongan PPh Pasal 21 karyawan.

2. Untuk mengetahui jumlah take home pay karyawan yang menerima tunjangan dan yang tidak menerima tunjangan.

3. Untuk mengetahui apakah jumlah pemotongan $\mathrm{PPh}$ Pasal 21 karyawan sudah sesuai dengan Undang-Undang PPh No. 36 tahun 2008.

\subsubsection{Manfaat Penelitian}

Manfaat dari penelitian ini dapat berguna bagi CV Saga Retailindo Sorong sebagai bahan pertimbangan kedepannya untuk melaksanakan kewajibannya dalam memotong dan menyetor PPh 21 karyawan.

\section{Tinjauan Pustaka}

\subsection{Pengertian Pajak}

Pajak menurut Pasal 1 ayat 1 UndangUndang Republik Indonesia No. 6 Tahun 1983 sebagaimana telah diubah dengan Undang- 
Undang No. 16 Tahun 2009 tentang Ketentuan Umum dan Tata Cara Perpajakan adalah kontribusi wajib kepada negara yang terutang oleh orang pribadi atau badan yang bersifat memaksa berdasarkan Undang-Undang, dengan tidak mendapatkan imbalan secara langsung dan digunakan untuk keperluan negara bagi sebesar-besarnya kemakmuran rakyat. Sedangkan definisi pajak menurut Meliala (2010:4), adalah iuran rakyat kepada kas negara berdasarkan undang-undang sebagai perwujudan pengabdian dan peran serta rakyat untuk membiayai negara dan pembangunan nasional.

\subsection{Pajak Penghasilan}

Menurut Pasal 1 Undang-Undang No. 7 Tahun 1983 sebagaimana telah diubah dengan Undang-Undang No. 36 tahun 2008 tentang Pajak Penghasilan, pajak penghasilan dikenakan terhadap subjek pajak atas penghasilan yang diterima atau diperolehnya dalam tahun pajak. Undang-Undang ini mengatur pengenaan Pajak Penghasilan terhadap subjek pajak berkenaan dengan penghasilan yang diterima atau diperolehnya dalam tahun pajak. Subjek pajak tersebut dikenai pajak apabila menerima atau memperoleh penghasilan. Subjek pajak yang menerima atau memperoleh penghasilan, dalam Undang-Undang ini disebut Wajib Pajak. Wajib Pajak dikenai pajak atas penghasilan yang diterima atau diperolehnya selama satu tahun pajak atau dapat pula dikenai pajak untuk penghasilan dalam bagian tahun pajak apabila kewajiban pajak subjektif-nya dimulai atau berakhir dalam tahun pajak.

\subsection{Pajak Penghasilan Pasal 21}

Menurut Forethought (2013:14), Pajak Penghasilan ( $\mathrm{PPh}$ ) Pasal 21 adalah pemotongan pajak atas penghasilan berupa gaji, upah, honorarium, tunjangan, dan pembayaran lain dengan nama dan dalam bentuk apapun sehubungan dengan pekerjaan atau jabatan, jasa dan kegiatan yang dilakukan oleh orang pribadi Subjek Pajak Dalam Negeri.

\subsection{Wajib Pajak Penghasilan Pasal 21}

Penerima penghasilan yang dipotong $\mathrm{PPh}$

Pasal 21 menurut Forethought (2013:14-16) adalah orang pribadi yang merupakan pegawai, penerima uang pesangon, pensiun atau uang manfaat pensiun, tunjangan hari tua, atau jaminan hari tua, termasuk ahli warisnya, bukan pegawai yang menerima atau memperoleh penghasilan sehubungan dengan pemberian jasa, anggota dewan komisaris atau dewan pengawas yang tidak merangkap sebagai Pegawai Tetap pada perusahaan yang sama, mantan pegawai, Peserta kegiatan yang menerima atau memperoleh penghasilan sehubungan dengan keikutsertaannya dalam suatu kegiatan.

\subsection{Objek Pajak Penghasilan Pasal 21}

Menurut Forethought (2013:14),

Penghasilan yang dipotong PPh Pasal 21 adalah Penghasilan berupa gaji, upah, honorarium, tunjangan, dan pembayaran lain dengan nama dan dalam bentuk apapun sehubungan dengan pekerjaan atau jabatan, jasa dan kegiatan yang dilakukan oleh orang pribadi Subjek Pajak Dalam Negeri.

\subsection{Pemotong Pajak Penghasilan Pasal 21}

Menurut Forethought (2013: 2-4),

pemotong $\mathrm{PPh}$ Pasal 21 yang selanjutnya disingkat Pemotong Pajak meliputi:

a. Pemberi kerja yang membayar gaji, upah, honorarium, tunjangan, dan pembayaran lain sebagai imbalan sehubungan dengan pekerjaan.

b. Bendahara pemerintah

c. Dana pensiun atau badan lain yang membayarkan uang pensiun dan pembayaran lain dengan nama apapun dalam rangka pensiun.

d. Badan yang membayar honorarium, komisi, fee, atau pembayaran lain.

e. Penyelenggara kegiatan, termasuk badan pemerintah, organisasi yang bersifat nasional dan internasional, perkumpulan, orang pribadi serta lembaga lainnya yang menyelenggarakan kegiatan, yang membayar honorarium, hadiah, atau penghargaan dalam bentuk apapun kepada Wajib Pajak orang pribadi berkenaan dengan suatu kegiatan.

\subsection{Tarif Pajak Penghasilan Pasal 21}

Tarif pajak penghasilan menurut Pasal 17 Undang-Undang No.36 Tahun 2008 tentang Perubahan Keempat Atas Undang-Undang No. 
7 Tahun 1983 tentang Pajak Penghasilan, adalah sebagai berikut:

Tabel 2.1

Tarif Pajak Pasal 17 Undang-Undang No.36 Tahun 2008 Bagi Wajib Pajak Orang Pribadi

\begin{tabular}{|l|c|}
\hline Lapisan Penghasilan Kena Pajak & $\begin{array}{c}\text { Tarif } \\
\text { Pajak }\end{array}$ \\
\hline $\begin{array}{l}\text { Sampai dengan Rp 50.000.000,00 } \\
\text { (lima puluh juta rupiah) }\end{array}$ & $5 \%$ \\
\hline $\begin{array}{l}\text { Di atas Rp 50.000.000,00 (lima } \\
\text { puluh juta rupiah) sampai dengan }\end{array}$ & $15 \%$ \\
$\begin{array}{l}\text { Rp 250.000.000,00 (dua ratus lima } \\
\text { puluh juta rupiah) }\end{array}$ & $25 \%$ \\
\hline $\begin{array}{l}\text { Di atas Rp 250.000.000,00 (dua } \\
\text { ratus lima puluh juta rupiah) sampai } \\
\text { dengan Rp 500.000.000,00 (lima } \\
\text { ratus juta rupiah) }\end{array}$ & $30 \%$ \\
\hline $\begin{array}{l}\text { Di atas Rp 500.000.000,00 (lima } \\
\text { ratus juta rupiah) }\end{array}$ & \\
\hline
\end{tabular}

Sumber: Undang-Undang No. 36 Tahun 2008

\subsection{Penghasilan Tidak Kena Pajak}

Penghasilan Tidak Kena Pajak (PTKP) adalah pengurangan terhadap penghasilan bruto orang pribadi atau perseorangan sebagai wajib pajak dalam menghitung penghasilan kena pajak yang menjadi objek pajak penghasilan yang harus dibayar wajib pajak di Indonesia. Besarnya Penghasilan Tidak Kena Pajak sesuai dengan Peraturan Menteri Keuangan No.122/PMK.010/2015 tentang penyesuaian besarnya Penghasilan Tidak Kena Pajak menggantikan Peraturan Menteri Keuangan No.162/PMK.011/2012, yaitu:

a. Rp 24.300.000,00 disesuaikan menjadi $\mathrm{Rp}$ 36.000.000,00 untuk diri Wajib Pajak orang pribadi;

b. Rp 2.025.000,00 disesuaikan menjadi $\mathrm{Rp}$ 3.000.000,00 tambahan untuk Wajib Pajak yang kawin;

c. $\mathrm{Rp} 24.300 .000,00$ disesuaikan menjadi $\mathrm{Rp}$ 36.000.000,00 tambahan untuk seorang istri yang penghasilannya digabung dengan penghasilan suami; dan

d. Rp 2.025.000,00 disesuaikan menjadi Rp 3.000.000,00 tambahan untuk setiap anggota keluarga sedarah dan keluarga semenda dalam garis keturunan lurus serta anak angkat, yang menjadi tanggungan sepenuhnya, paling banyak 3 orang untuk setiap keluarga.

Penghasilan Tidak Kena Pajak (PTKP) per bulan adalah PTKP per tahun dibagi 12, sebesar:

a. Rp 3.000.000,00 untuk diri Wajib Pajak orang pribadi;

b. Rp 250.000,00 untuk Wajib Pajak yang kawin; dan

c. Rp 250.000,00 tambahan untuk setiap anggota keluarga sedarah dan keluarga semenda dalam garis keturunan lurus serta anak angkat, yang menjadi tanggungan sepenuhnya, paling banyak 3 orang untuk setiap keluarga.

Perubahan besarnya Penghasilan Tidak Kena Pajak (PTKP) terakhir menurut Peraturan Menteri Keuangan No. 101/PMK.010/2016 tentang Penyesuaian Besarnya Penghasilan Tidak Kena Pajak, yaitu:

a. Rp 54.000.000,00 untuk diri Wajib Pajak orang pribadi;

b. Rp 4.500.000,00 tambahan untuk Wajib Pajak yang kawin;

c. Rp 54.000.000,00 tambahan untuk seorang istri yang penghasilannya digabung dengan penghasilan suami;

d. Rp 4.500.000,00 tambahan untuk setiap anggota keluarga sedarah dan keluarga semenda dalam garis keturunan lurus serta anak angkat yang menjadi tanggungan sepenuhnya, paling banyak 3 (tiga) orang untuk setiap keluarga.

Besarnya Penghasilan Tidak Kena Pajak bagi karyawati berlaku ketentuan sebagai berikut:

a. Bagi karyawati kawin, sebesar PTKP untuk dirinya sendiri; dan

b. Bagi karyawati tidak kawin, sebesar PTKP untuk dirinya sendiri ditambah PTKP untuk keluarga yang menjadi tanggungan sepenuhnya.

Dalam hal karyawati kawin dapat menunjukkan keterangan tertulis dari Pemerintah Daerah setempat serendahrendahnya kecamatan yang menyatakan bahwa suaminya tidak menerima atau memperoleh penghasilan, besarnya PTKP adalah PTKP untuk dirinya sendiri ditambah PTKP untuk status kawin dan PTKP untuk keluarga yang menjadi tanggungan sepenuhnya. Besarnya PTKP ditentukan berdasarkan keadaan awal pada tahun kalender. 


\subsection{Tata Cara Perhitungan dan} Pemotongan Pajak Penghasilan Pasal 21

Tata cara perhitungan PPh Pasal 21 bulanan atas Penghasilan Teratur Pegawai Tetap menurut Meliala (2010:148), yaitu :

1. a. Untuk menghitung PPh Pasal 21 atas penghasilan pegawai tetap, terlebih dahulu dihitung seluruh penghasilan bruto yang diterima atau diperoleh selama sebulan, yang meliputi seluruh gaji, segala jenis tunjangan dan pembayaran teratur lainnya, termasuk uang lembur (overtime) dan pembayaran sejenisnya.

b. Untuk perusahaan yang masuk program jamsostek, premi jaminan kecelakaan kerja (JKK), premi jaminan kematian (JK) yang dibayar oleh pemberi kerja merupakan penghasilan bagi pegawai. Ketentuan yang sama diberlakukan juga bagi premi asuransi kesehatan, asuransi kecelakaan kerja, asuransi jiwa, asuransi dwiguna, dan asuransi bea siswa yang dibayarkan oleh pemberi kerja untuk pegawai kepada perusahaan asuransi lainnya. Dalam menghitung PPh Pasal 21 , premi tersebut digabungkan dengan penghasilan bruto yang dibayarkan oleh pemberi kerja kepada pegawai.

c. Selanjutnya dihitung jumlah penghasilan netto sebulan yang diperoleh dengan cara mengurangi penghasilan bruto sebulan dengan biaya jabatan, serta iuran pensiun, iuran jaminan hari tua, dan/atau iuran tunjangan hari tua yang dibayar sendiri oleh pegawai yang bersangkutan melalui pemberi kerja kepada dana pensiun yang pendiriannya telah disahkan oleh Menteri Keuangan atau kepada Badan Penyelenggara Program Jamsostek.

2. a. untuk memperoleh penghasilan netto setahun, penghasilan netto dikalikan 12 .

b. Dalam hal seorang pegawai tetap, kewajiban pajak subjektifnya sebagai wajib pajak dalam negeri sudah ada sejak awal tahun, tetapi mulai bekerja setelah bulan Januari, maka penghasilan netto yang disetahunkan tersebut dihitung dengan mengalikan penghasilan netto sebulan dengan banyaknya bulan sejak pegawai yang bersangkutan mulai bekerja sampai dengan bulan Desember. c. Penghasilan netto yang disetahunkan pada huruf a atau $b$ diatas, selanjutnya dikurangi dengan PTKP untuk memperoleh Penghasilan Kena Pajak. Atas dasar Penghasilan Kena Pajak tersebut kemudian dihitung PPh Pasal 21 setahun, dengan menerapkan tarif pasal 17 ayat (1) huruf a UU PPh.

d. Untuk memperoleh jumlah PPh Pasal 21 sebulan, jumlah PPh Pasal 21 setahun atas penghasilan sebagaimana pada huruf a dibagi dengan 12 .

e. Untuk memperoleh jumlah PPh Pasal 21 sebulan atas penghasilan sebagaimana dimaksud pada huruf $b$, jumlah PPh Pasal 21 setahun dibagi dengan banyaknya bulan pegawai yang bersangkutan bekerja.

\subsection{Metode Pemotongan Pajak Penghasilan Pasal 21 Karyawan}

Pemotongan PPh Pasal 21 oleh

perusahaan atas penghasilan karyawan bersifat mandatory (wajib). Perusahaan dapat menentukan kebijakan terkait dengan pemotongan PPh Pasal 21 sepanjang kebijakan tersebut tidak bertentangan dengan ketentuan yang diatur dalam peraturan perpajakan. Berkaitan dengan PPh Pasal 21 karyawan, ada beberapa alternatif pembebanan yang dapat diambil oleh perusahaan, antara lain:

a. PPh Pasal 21 ditanggung oleh karyawan

Karyawan menanggung beban pajaknya sendiri. Metode untuk menghitung PPh Pasal 21 yang dibebankan kepada karyawan dikenal dengan Metode Gross (Gross Method). Dengan metode ini penghasilan yang diterima karyawan akan dipotong sesuai besarnya pajak penghasilan terutang masing-masing karyawan sehingga menjadikan take home pay karyawan berkurang. Dalam metode ini, tidak menimbulkan beban bagi perusahaan dan tidak mempengaruhi laba rugi, perusahaan hanya berkewajiban memungut, melaporkan dan menyetor ke Kantor Pajak.

b. PPh Pasal 21 ditanggung perusahaan

Perusahaan menanggung beban pajak karyawan baik sebagian atau seluruhnya dalam bentuk Benefit in Kind (BIK). Metode untuk menghitung PPh Pasal 21 yang ditanggung oleh perusahaan dalam bentuk Benefit in Kind (BIK) dikenal dengan metode Net (Net Method). 
Dengan metode ini penghasilan yang diterima karyawan dapat diterima secara utuh tanpa adanya pengurangan PPh Pasal 21, kecuali jika perusahaan hanya menanggung sebagian. Pemilihan metode ini membutuhkan analisa komprehensif karena selain menjadi beban, pengeluaran perusahaan untuk menanggung PPh Pasal 21 karyawan tidak dapat dibebankan secara fiskal dalam menghitung PPh Badan. Dalam hal PPh Pasal 21 atas gaji pegawai ditanggung oleh pemberi kerja, pajak yang ditanggung pemberi kerja tersebut termasuk dalam pengertian kenikmatan dan bukan merupakan penghasilan pegawai yang bersangkutan.

c. PPh Pasal 21 ditanggung perusahaan dengan cara memberikan tunjangan pajak.

Perusahaan menanggung beban pajak karyawan baik sebagian maupun seluruhnya dengan cara memberikan tunjangan pajak. Pemberian tunjangan pajak sifatnya sama dengan tunjangan lainnya. Penghasilan karyawan yang bersangkutan akan bertambah dengan diberikannya tunjangan pajak. Pemilihan metode ini membutuhkan analisa komprehensif meskipun pengeluaran perusahaan untuk menanggung PPh Pasal 21 karyawan secara fiskal dapat dibebankan sebagai biaya dalam menghitung PPh Badan. Tunjangan pajak dapat diberikan secara Flat (tetap) maupun dengan melakukan Gross $U p$ (jumlahnya tidak tetap melainkan disesuaikan dengan besarnya pajak yang harus dipotong dari penghasilan karyawan atau proporsional). Metode Gross Up memberikan tunjangan pajak sebesar $100 \%$ dari $\mathrm{PPh}$ yang harus dipotong. Bagi pemberi kerja tunjangan pajak tersebut dapat dianggap sebagai biaya, sedangkan bagi pekerja tunjangan pajak dianggap sebagai penghasilan.

\section{Metodologi Penelitian}

\subsection{Jenis dan Sumber Data}

Data yang digunakan dalam penelitian ini yaitu data primer dan data sekunder. Data primer yaitu data yang diperoleh langsung dari objek yang diteliti. Data primer berupa sejarah singkat perusahaan, struktur organisasi, uraian tugas dan tanggung jawab, dan dokumen pendukung yang digunakan berupa daftar karyawan, daftar gaji karyawan, perhitungan pajak penghasilan pasal 21 pada karyawan menurut perusahaan, dan rekapitulasi pemotongan pajak penghasilan pasal 21 oleh perusahaan. Sedangkan data sekunder yaitu data yang diperoleh dalam bentuk sudah jadi atau data yang telah dipublikasikan oleh pihak lain, yaitu dengan membaca dan mempelajari bukubuku, artikel dan lain-lain yang berhubungan dengan penulisan penelitian ini.

\subsection{Metode Pengumpulan Data}

Metode yang digunakan dalam pengumpulan data yaitu studi lapangan, merupakan metode pengumpulan atau memperoleh data langsung melalui pengamatan/observasi secara langsung objek yang diteliti dan wawancara dengan pihakpihak yang berwenang pada masalah yang diteliti dan studi pustaka, merupakan metode perolehan data dengan mempelajari buku-buku, literatur-literatur serta jurnal yang berkaitan dengan objek penelitian dan juga melalui media elektronik seperti internet yang akan digunakan sebagai acuan dalam penelitian

\subsection{Analisis Data}

Metode analisis data yang penulis terapkan dalam penelitian ini adalah metode kualitatif dan kuantitatif. Metode Kualitatif, yaitu metode analisis data yang bukan berupa angka atau data berupa penjelasan yang tidak dapat dinyatakan dalam bentuk angka. Analisis data dilakukan dengan cara mempelajari dan menguji apakah ketentuan Undang-Undang Perpajakan yang berlaku telah diterapkan oleh perusahaan dalam melakukan perhitungan dan pemotongan $\mathrm{PPh}$ Pasal 21 karyawan. Sedangkan metode kuantitatif, yaitu metode analisis data dalam bentuk angka. Analisis data dilakukan dengan cara perhitungan angkaangka berdasarkan data-data yang tersedia untuk menguji apakah perusahaan dalam menghitung dan memotong PPh Pasal 21 karyawan telah sesuai dengan ketentuan Undang-Undang Perpajakan yang berlaku. 
Dalam penelitian ini metode yang digunakan untuk melakukan perhitungan $\mathrm{PPh}$ Pasal 21 terutang yaitu perhitungan $\mathrm{PPh}$ Pasal 21 bagi karyawan tetap, yaitu;

PPh Pasal $21=($ Penghasilan netto - PTKP) $\mathrm{x}$ tarif Pasal 17 UU PPh

$=$ (Penghasilan bruto - Biaya Jabatan - iuran pensiun dan iuran JHT yang dibayar oleh karyawan - PTKP) $x$ tarif Pasal 17 UU PPh

\section{Pembahasan}

\subsection{Metode Perhitungan Pajak Penghasilan Pasal 21 Karyawan CV Saga Retailindo Sorong}

Metode perhitungan PPh Pasal 21 merupakan hal yang sangat penting dalam proses pemotongan PPh Pasal 21 yang dipotong dari gaji karyawan. Peraturan perpajakan yang berlaku harus benar-benar diterapkan dalam melakukan perhitungan PPh Pasal 21, sehingga tidak terjadi kesalahan perhitungan maupun pemotongan $\mathrm{PPh}$ Pasal 21 yang akan mempengaruhi take home pay karyawan. Metode perhitungan $\mathrm{PPh}$ Pasal 21 yang diterapkan oleh CV Saga Retailindo Sorong yaitu:

1. Untuk menghitung $\mathrm{PPh}$ Pasal 21 atas penghasilan karyawan tetap, terlebih dahulu dihitung seluruh penghasilan yang diterima atau diperoleh selama sebulan, yang meliputi gaji pokok, tunjangan tetap, dan upah lembur.

2. Premi Jaminan Kecelakaan Kerja (JKK), Premi Jaminan Kematian (JK) dan premi asuransi kesehatan (BPJS Askes) yang dibayarkan oleh perusahaan merupakan penghasilan bagi karyawan yang dijumlahkan dengan penghasilan sebulan karyawan untuk memperoleh penghasilan bruto karyawan.

3. Menghitung jumlah penghasilan netto sebulan yang diperoleh dengan cara mengurangi penghasilan bruto sebulan dengan biaya jabatan, iuran Jaminan Pensiun (JP), iuran Jaminan Hari Tua (JHT) yang dibayar sendiri oleh karyawan yang bersangkutan melalui perusahaan kepada BPJS Ketenagakerjaan.
4. Penghasilan Kena Pajak (PKP) dihitung dengan cara penghasilan netto sebulan dikurang dengan Penghasilan Tidak Kena Pajak (PTKP) yang terlebih dahulu dibagi 12 (dua belas) untuk memperoleh PTKP per bulan.

5. Untuk menghitung PPh Pasal 21 terutang, maka Penghasilan Kena Pajak sebulan disetahunkan dan menerapkan tarif pasal 17 ayat (1) huruf a Undang-Undang Pajak Penghasilan.

6. Setelah memperoleh $\mathrm{PPh}$ Pasal 21 terutang untuk setahun maka PPh Pasal 21 setahun dibagi 12 untuk memperoleh PPh Pasal 21 terutang sebulan.

Setelah diperoleh jumlah PPh Pasal 21 yang terutang maka dilakukan pemotongan $\mathrm{PPh}$ Pasal 21 karyawan pada perhitungan take home pay karyawan bulan berikutnya. Sedangkan untuk penyetoran $\mathrm{PPh}$ Pasal 21 dilakukan paling lama 10 (sepuluh) hari setelah masa pajak berakhir.

\subsection{Komponen Perhitungan Pajak Penghasilan Pasal 21 Karyawan CV Saga Retailindo Sorong}

Untuk mengetahui proses perhitungan dan pemotongan $\mathrm{PPh}$ Pasal 21 karyawan, terlebih dahulu penulis mengidentifikasi komponen-komponen yang digunakan perusahaan untuk melakukan perhitungan yaitu:

1. Penghasilan bruto karyawan yang terdiri dari:

a. Gaji pokok

Adalah imbalan dasar yang dibayarkan kepada karyawan atas pekerjaan yang dilakukan yang besarnya ditetapkan berdasarkan kesepakatan. Gaji pokok pada perusahaan didasarkan pada peraturan pemerintah tentang UMP (Upah Minimum Provinsi). Besarnya UMP yang berlaku untuk tahun 2014 dan 2015 yaitu:

UMP 2014 : Rp 1.870.000 / bulan atau Rp $22.440 .000 /$ tahun

UMP 2015 : Rp 2.015.000 / bulan atau Rp 24.180.000 / tahun

b. Tunjangan

Tunjangan adalah pembayaran kepada karyawan yang dibayar secara teratur bersamaan dengan gaji pokok yang jumlahnya ditentukan berdasarkan kebijakan pimpinan perusahaan. Tunjangan yang diberikan kepada karyawan terdiri dari 
tunjangan tetap yang diberikan hanya pada karyawan bagian tertentu dan tunjangan hari raya (THR) untuk seluruh karyawan. Tunjangan Hari Raya (THR) diberikan 1 kali dalam setahun bagi seluruh karyawan yang jumlahnya sebesar gaji pokok (sesuai UMP untuk tahun 2014 dan 2015).

c. Upah lembur

Upah lembur merupakan upah atas perpanjangan jam kerja dari jam kerja normal.

d. Program BPJS Ketenagakerjaan dan BPJS Kesehatan

Program BPJS Ketenagakerjaan yang diikuti perusahaan terdiri dari program Jaminan Kecelakaan Kerja (JKK) sebesar $0,24 \%$ dari gaji pokok karyawan, Jaminan Kematian (JK) sebesar 0,3\% dari gaji pokok karyawan, Jaminan Hari Tua (JHT) sebesar 3,7\% dari gaji pokok, dan Jaminan Pensiun (JP) sebesar 2\%. Sedangkan program BPJS Kesehatan yang diikuti perusahaan yaitu Asuransi Kesehatan (Askes) sebesar 4\% dari gaji pokok. Premi Jaminan Kecelakaan Kerja (JKK), premi Jaminan Kematian (JK) dan premi Asuransi Kesehatan (Askes) yang dibayar perusahaan akan dikenakan pajak karena termasuk dalam pengertian penghasilan yang menjadi objek pajak yang menambah penghasilan karyawan. Sedangkan premi Jaminan Hari Tua (JHT) dan premi Jaminan Pensiun (JP) yang dibayar perusahaan tidak dikenakan pajak karena pengenaan pajak atas iuran tersebut berarti mengurangi hak karyawan, oleh karena itu iuran tersebut dikecualikan sebagai objek pajak. Upah yang menjadi dasar perhitungan premi Jaminan Kecelakaan Kerja (JKK), premi Jaminan Kematian (JK) dan premi Asuransi Kesehatan (Askes) yang dipakai perusahaan yaitu Upah Minimum Provinsi untuk tahun 2014 dan 2015.

2. Komponen pengurang yang diperkenankan menurut Undang-Undang yang terdiri dari:

a. Biaya Jabatan; adalah biaya untuk mendapatkan, menagih dan memelihara penghasilan yang dapat dikurangkan dari penghasilan setiap orang yang bekerja sebagai Pegawai Tetap tanpa memandang mempunyai jabatan atau tidak. Perusahaan menetapkan Biaya Jabatan dengan jumlah yang sama untuk masingmasing karyawan sebesar Rp 1.300 .000 untuk tahun 2014 dan $\mathrm{Rp} 1.500 .000$ untuk tahun 2015.

b. Iuran yang dibayar oleh karyawan terdiri dari iuran Jaminan Hari Tua (JHT) dan iuran Jaminan Pensiun (JP) dan iuran Asuransi Kesehatan (Askes). Iuran Jaminan Hari Tua (JHT) sebesar 2\% dihitung dari gaji pokok dan iuran Jaminan Pensiun (JP) sebesar 1\% dari gaji pokok. Iuran Jaminan Pensiun mulai berlaku pada tanggal 1 Oktober 2015. Sedangkan iuran Asuransi Kesehatan tidak boleh dikurangkan dari penghasilan bruto karena bukan merupakan objek pajak. Sedangkan iuran Jaminan Pensiun mulai berlaku efektif sejak tanggal 1 Oktober 2015.

3. Penghasilan neto

Penghasilan neto diperoleh dari penghasilan bruto dikurangi biaya jabatan, iuran JHT dan iuran JP yang dibayar oleh karyawan.

4. Penghasilan Tidak Kena Pajak (PTKP)

Besarnya Penghasilan Tidak Kena Pajak (PTKP) yang dipakai perusahaan sebagai pengurang penghasilan neto berdasarkan pada Peraturan Menteri Keuangan No.162/PMK.011/2012 untuk tahun pajak 2014 dan Peraturan Menteri Keuangan No.122/PMK.010/2015 untuk tahun pajak 2015. Besarnya Penghasilan Tidak Kena Pajak ditetapkan berdasarkan status karyawan yang disajikan dalam tabel 4.1

Tabel 4.1

Penghasilan Tidak Kena Pajak Tahun 2014 dan 2015

\begin{tabular}{|c|c|c|}
\hline \multirow{2}{*}{$\begin{array}{c}\text { Ktatus } \\
\text { Karyawan }\end{array}$} & \multicolumn{2}{|c|}{ PTKP } \\
\cline { 2 - 4 } & $\mathbf{2 0 1 4}$ & $\mathbf{2 0 1 5}$ \\
\hline $\mathrm{TK} / 0$ & Rp 24.300.000 & Rp 36.000 .000 \\
\hline $\mathrm{TK} / 2$ & Rp 28.350.000 & Rp 42.000.000 \\
\hline K/0 & Rp 26.325.000 & Rp 39.000.000 \\
\hline K/1 & Rp 28.350.000 & Rp 42.000.000 \\
\hline K/2 & Rp 30.375.000 & Rp 45.000.000 \\
\hline K/3 & Rp 32.400.000 & Rp 48.000.000 \\
\hline
\end{tabular}

Sumber: CV Saga Retailindo Sorong

Catatan:

a) Status karyawan yang disajikan dalam tabel 4.1 berdasarkan peraturan pajak yaitu: 
TK/0 : Wajib Pajak tidak kawin dan tidak memiliki tanggungan

TK/2 : Wajib Pajak tidak kawin dan memiliki tanggungan 2 orang

K/0 : Wajib Pajak kawin, penghasilan istri dipisah dan tidak memiliki tanggungan

K/1 : Wajib Pajak kawin, penghasilan istri dipisah dan memiliki tanggungan 1 orang

$\mathrm{K} / 2$ : Wajib Pajak kawin, penghasilan istri dipisah dan memiliki tanggungan 2 orang

K/3 : Wajib Pajak kawin, penghasilan istri dipisah dan memiliki tanggungan 3 orang

5. Penghasilan Kena Pajak (PKP)

Penghasilan Kena Pajak diperoleh dari penghasilan neto dikurangi PTKP.

6. PPh Pasal 21 terutang

PPh Pasal 21 terutang dihitung dengan menerapkan tarif pasal 17 ayat (1) huruf a undang-undang pajak penghasilan.

Setelah memperoleh PPh Pasal 21 terutang maka pemotongan PPh Pasal 21 yang terutang dilakukan pada perhitungan take home pay karyawan bulan berikutnya.

\subsection{Tinjauan Perhitungan dan Pemotongan Pajak Penghasilan Pasal 21 Antara CV Saga Retailindo Sorong dengan Peraturan Perpajakan}

Jumlah karyawan tetap pada CV Saga Retailindo Sorong saat ini sebanyak 268 orang, dimana kewajiban perpajakannya dilakukan oleh CV Saga Retailindo Sorong sebagai pemberi kerja. Berdasarkan data yang penulis peroleh, untuk tahun 2014 dan 2015 sebanyak
232 karyawan tetap yang menanggung sendiri $\mathrm{PPh}$ Pasal 21 terutang yang dipotong dari penghasilan karyawan. Setelah melakukan perhitungan, penulis membandingkan hasil perhitungan menurut peraturan perpajakan dan perhitungan menurut perusahaan. Perbandingan $\mathrm{PPh}$ Pasal 21 antara perhitungan peraturan perpajakan dan perhitungan perusahaan penulis sajikan pada tabel 4.2 dan tabel 4.3. 
Tabel 4.2

Perbandingan Hasil Perhitungan PPh Pasal 21

Menurut Perhitungan Perusahaan dan Peraturan Perpajakan Tahun 2014

\begin{tabular}{|r|l|rr|rr|rr|}
\hline \multirow{2}{*}{$\begin{array}{c}\text { Jumlah } \\
\text { Karyawan }\end{array}$} & \multirow{2}{*}{ Bagian } & \multicolumn{5}{|c|}{ Pajak Penghasilan Pasal 21 } \\
\cline { 3 - 8 } & & Perus ahaan & \multicolumn{2}{c|}{$\begin{array}{c}\text { UU.36 tahun } \\
\mathbf{2 0 0 8}\end{array}$} & $\begin{array}{l}\text { Selisih Lebih } \\
\text { (kurang) }\end{array}$ \\
\hline 1 & Administrasi & $\mathrm{Rp}$ & 983.950 & $\mathrm{Rp}$ & 934.650 & $\mathrm{Rp}$ & 49.300 \\
\hline 4 & Administrasi Gudang & $\mathrm{Rp}$ & 2.135 .200 & $\mathrm{Rp}$ & 2.028 .000 & $\mathrm{Rp}$ & 107.200 \\
\hline 1 & Ass. Administrasi & $\mathrm{Rp}$ & 83.950 & $\mathrm{Rp}$ & 79.650 & $\mathrm{Rp}$ & 4.300 \\
\hline 2 & CS & $\mathrm{Rp}$ & 1.146 .350 & $\mathrm{Rp}$ & 1.083 .750 & $\mathrm{Rp}$ & 62.600 \\
\hline 1 & $\mathrm{IT}$ & $\mathrm{Rp}$ & 1.130 .050 & $\mathrm{Rp}$ & 1.058 .250 & $\mathrm{Rp}$ & 71.800 \\
\hline 13 & Karyawan Gudang & $\mathrm{Rp}$ & 11.375 .160 & $\mathrm{Rp}$ & 10.744 .200 & $\mathrm{Rp}$ & 630.960 \\
\hline 22 & Kasir & $\mathrm{Rp}$ & 9.662 .350 & $\mathrm{Rp}$ & 9.171 .750 & $\mathrm{Rp}$ & 490.600 \\
\hline 3 & Kepala Counter & $\mathrm{Rp}$ & 1.196 .400 & $\mathrm{Rp}$ & 1.116 .000 & $\mathrm{Rp}$ & 80.400 \\
\hline 2 & Kepala Kasir & $\mathrm{Rp}$ & 1.067 .600 & $\mathrm{Rp}$ & 1.014 .000 & $\mathrm{Rp}$ & 53.600 \\
\hline 156 & Pramuniaga & $\mathrm{Rp}$ & 62.730 .300 & $\mathrm{Rp}$ & 59.485 .500 & $\mathrm{Rp}$ & 3.244 .800 \\
\hline 5 & Security & $\mathrm{Rp}$ & 4.652 .750 & $\mathrm{Rp}$ & 4.353 .750 & $\mathrm{Rp}$ & 299.000 \\
\hline 14 & Staff & $\mathrm{Rp}$ & 18.554 .450 & $\mathrm{Rp}$ & 17.549 .250 & $\mathrm{Rp}$ & 1.005 .200 \\
\hline 4 & Supir & $\mathrm{Rp}$ & 2.532 .700 & $\mathrm{Rp}$ & 2.395 .500 & $\mathrm{Rp}$ & 137.200 \\
\hline 4 & Teknisi & $\mathrm{Rp}$ & 2.127 .700 & $\mathrm{Rp}$ & 1.990 .500 & $\mathrm{Rp}$ & 137.200 \\
\hline $\mathbf{2 3 2}$ & & $\mathrm{Rp} \mathbf{1 1 9 . 3 7 8 . 9 1 0}$ & $\mathrm{Rp} \mathbf{1 1 3 . 0 0 4 . 7 5 0}$ & $\mathrm{Rp6.374.160}$ \\
\hline
\end{tabular}

Sumber: Hasil Olah Data

Tabel 4.3

Perbandingan Hasil Perhitungan PPh Pasal 21

Menurut Perhitungan Perusahaan dan Peraturan Perpajakan

Tahun 2015

\begin{tabular}{|c|c|c|c|c|c|c|c|}
\hline \multirow{3}{*}{\begin{tabular}{|r}
$\begin{array}{c}\text { Jumlah } \\
\text { Karyawan }\end{array}$ \\
1 \\
\end{tabular}} & \multirow{3}{*}{$\begin{array}{l}\text { Bagian } \\
\text { istrasi } \\
\end{array}$} & \multicolumn{6}{|c|}{ Pajak Penghasilan Pasal 21} \\
\hline & & \multicolumn{2}{|c|}{ Perusahaan } & \multicolumn{2}{|c|}{\begin{tabular}{|c|} 
UU No.36 tahun \\
2008 \\
\end{tabular}} & \multicolumn{2}{|r|}{ Selisih } \\
\hline & & $\mathrm{Rp}$ & 602.400 & $\mathrm{Rp}$ & 552.200 & $\mathrm{Rp}$ & 50.200 \\
\hline 4 & Administrasi Gudang & $\mathrm{Rp}$ & 222.600 & $\mathrm{Rp}$ & 131.000 & $\mathrm{Rp}$ & 91.600 \\
\hline 1 & Ass. Administrasi & $\mathrm{Rp}$ & - & $\mathrm{Rp}$ & 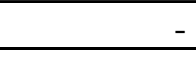 & $\mathrm{Rp}$ & - \\
\hline 2 & $\mathrm{CS}$ & $\mathrm{Rp}$ & 321.300 & $\mathrm{Rp}$ & 257.500 & $\mathrm{Rp}$ & 63.800 \\
\hline 1 & IT & $\mathrm{Rp}$ & 625.650 & $\mathrm{Rp}$ & 551.750 & $\mathrm{Rp}$ & 73.900 \\
\hline 13 & Karyawan Gudang & $\mathrm{Rp}$ & 5.943 .450 & $\mathrm{Rp}$ & 5.294 .750 & $\mathrm{Rp}$ & 648.700 \\
\hline 22 & Kasir & $\mathrm{Rp}$ & - & $\mathrm{Rp}$ & - & $\mathrm{Rp}$ & - \\
\hline 3 & Kepala Counter & $\mathrm{Rp}$ & 351.300 & $\mathrm{Rp}$ & 293.500 & $\mathrm{Rp}$ & 57.800 \\
\hline 2 & Kepala Kasir & $\mathrm{Rp}$ & 231.300 & $\mathrm{Rp}$ & 179.500 & $\mathrm{Rp}$ & 51.800 \\
\hline 156 & Pramuniaga & $\mathrm{Rp}$ & - & $\mathrm{Rp}$ & - & $\mathrm{Rp}$ & - \\
\hline 5 & Security & $\mathrm{Rp}$ & 2.228 .250 & $\mathrm{Rp}$ & 1.918 .750 & $\mathrm{Rp}$ & 309.500 \\
\hline 14 & Staff & $\mathrm{Rp}$ & 12.809 .100 & $\mathrm{Rp}$ & 11.774 .500 & $\mathrm{Rp}$ & 1.034 .600 \\
\hline 4 & Supir & $\mathrm{Rp}$ & 886.950 & $\mathrm{Rp}$ & 782.250 & $\mathrm{Rp}$ & 104.700 \\
\hline 4 & Teknisi & $\mathrm{Rp}$ & 441.300 & $\mathrm{Rp}$ & 371.500 & $\mathrm{Rp}$ & 69.800 \\
\hline 232 & & $\mathbf{R p}$ & 24.663 .600 & $\mathbf{R p}$ & 22.107 .200 & $\mathbf{R p}$ & 2.556 .400 \\
\hline
\end{tabular}

Sumber: Hasil Olah Data 
Berdasarkan perbandingan diatas, terdapat perbedaan perhitungan PPh Pasal 21 antara perhitungan perusahaan dan perhitungan menurut peraturan perpajakan yaitu:

a. Untuk tahun 2014 perhitungan PPh Pasal 21 menurut perhitungan perusahaan sebesar Rp 119.378.910 dan menurut peraturan perpajakan sebesar $\mathrm{Rp}$ 113.004.750, selisihnya sebesar Rp 6.374.160 merupakan lebih bayar bagi perusahaan.

b. Untuk tahun 2015 perhitungan PPh Pasal 21 menurut perhitungan perusahaan sebesar Rp 24.663.600 dan menurut peraturan perpajakan sebesar Rp 22.107.200, selisihnya sebesar Rp 2.556.400 merupakan lebih bayar bagi perusahaan.

Dengan adanya selisih lebih tersebut berarti karyawan sebagai wajib pajak memiliki kelebihan pembayaran pajak di kas negara, dan karyawan berhak atas pengembalian kelebihan tersebut. Pengembalian kelebihan pajak dapat dilakukan melalui dua cara yaitu kompensasi dan restitusi. Dengan cara kompensasi, maka kelebihan pembayaran tersebut dialihkan sebagai pengurang pajak terutang pada tahun pajak berikutnya. Sedangkan dengan cara restitusi berarti karyawan menerima kembali sejumlah uang pajak yang lebih dibayar tersebut. Namun jika baik kompensasi maupun restitusi tidak dapat dilakukan perusahaan, maka sebaiknya untuk perhitungan $\mathrm{PPh}$ Pasal 21 karyawan untuk kedepannya perusahaan benar-benar menerapkan peraturan perpajakan yang telah ditetapkan oleh pemerintah.

Perbedaan jumlah PPh Pasal 21 menurut perhitungan perusahaan dan menurut peraturan perpajakan disebabkan Biaya Jabatan yang ditetapkan perusahaan untuk tahun 2014 dan tahun 2015 jumlahnya sama untuk setiap karyawan yaitu sebesar Rp 1.300.000 dan Rp 1.500.000, sedangkan mengacu pada Peraturan Dirjen Pajak No.PER-32/PJ/2015 biaya jabatan ditetapkan sebesar 5\% dari penghasilan bruto setinggi-tingginya $\mathrm{Rp} 500.000$ sebulan dan Rp 6.000.000 setahun.

Dalam hal perhitungan take home pay karyawan setiap bulannya unsur penghasilan karyawan terdiri dari gaji pokok, lembur, tunjangan tetap dan Tunjangan Hari Raya (THR) yang diberikan kepada karyawan sebanyak 1 kali dalam setahun sebesar gaji pokok 1 bulan. Sedangkan pengurang penghasilan karyawan yaitu iuran Jaminan Hari Tua, iuran Jaminan Pensiun, iuran Askes dan PPh Pasal 21 bulan sebelumnya yang dipotong dari gaji karyawan. Jumlah penghasilan yang diterima karyawan berbeda untuk setiap bagian, hal ini dikarenakan tunjangan yang diberikan berbeda untuk masing-masing bagian. Rekap jumlah take home pay karyawan selama 1 tahun penulis sajikan pada tabel 4.4 dan tabel 4.5

Catatan:

1. Perhitungan take home pay karyawan diperoleh dari:

Tahun 2014 = (Gaji Pokok + Lembur + Tunjangan Tetap + THR) (Iuran JHT + Iuran Askes + PPh Pasal 21 terutang)

Tahun 2015 $=($ Gaji Pokok + Lembur + Tunjangan Tetap + THR) (Iuran JHT + Iuran Askes + Iuran JP $+\mathrm{PPh}$ Pasal 21 terutang) 
Tabel 4.4

Daftar Rekapitulasi Take Home Pay Karyawan CV Saga Retailindo Sorong Tahun 2014

\begin{tabular}{|l|rr|r|lr|}
\hline \multicolumn{1}{|c|}{ Bagian } & \multicolumn{2}{c|}{$\begin{array}{c}\text { Take Home Pay / } \\
\text { karyawan }\end{array}$} & $\begin{array}{c}\text { Jumlah } \\
\text { Karyawan }\end{array}$ & \multicolumn{2}{c|}{ Total } \\
\hline Administrasi & $\mathrm{Rp}$ & 42.604 .050 & 1 & $\mathrm{Rp}$ & 42.604 .050 \\
\hline Administrasi Gudang & $\mathrm{Rp}$ & 34.050 .500 & 4 & $\mathrm{Rp}$ & 136.202 .000 \\
\hline Ass. Administrasi & $\mathrm{Rp}$ & 25.504 .050 & 1 & $\mathrm{Rp}$ & 25.504 .050 \\
\hline CS & $\mathrm{Rp}$ & 35.811 .125 & 2 & $\mathrm{Rp}$ & 71.622 .250 \\
\hline IT & $\mathrm{Rp}$ & 51.454 .250 & 1 & $\mathrm{Rp}$ & 51.454 .250 \\
\hline Karyawan Gudang & $\mathrm{Rp}$ & 42.109 .288 & 13 & $\mathrm{Rp}$ & 547.420 .740 \\
\hline Kasir & $\mathrm{Rp}$ & 32.345 .102 & 22 & $\mathrm{Rp}$ & 711.592 .250 \\
\hline Kepala Counter & $\mathrm{Rp}$ & 34.185 .500 & 3 & $\mathrm{Rp}$ & 102.556 .500 \\
\hline Kepala Kasir & $\mathrm{Rp}$ & 34.050 .500 & 2 & $\mathrm{Rp}$ & 68.101 .000 \\
\hline Pramuniaga & $\mathrm{Rp}$ & 31.782 .183 & 156 & $\mathrm{Rp}$ & 4.958 .020 .500 \\
\hline Satpam & $\mathrm{Rp}$ & 46.853 .750 & 5 & $\mathrm{Rp}$ & 234.268 .750 \\
\hline Staff & $\mathrm{Rp}$ & 51.258 .982 & 14 & $\mathrm{Rp}$ & 717.625 .750 \\
\hline Supir & $\mathrm{Rp}$ & 36.951 .125 & 4 & $\mathrm{Rp}$ & 147.804 .500 \\
\hline Teknisi & $\mathrm{Rp}$ & 37.052 .375 & 4 & $\mathrm{Rp}$ & 148.209 .500 \\
\hline & $\mathrm{Rp}$ & $\mathbf{5 3 6 . 0 1 2 . 7 8 0}$ & $\mathbf{2 3 2}$ & $\mathrm{Rp}$ & $\mathbf{7 . 9 6 2 . 9 8 6 . 0 9 0}$ \\
\hline
\end{tabular}

Sumber: CV Saga Retailindo Sorong

Tabel 4.5

Daftar Rekapitulasi Take Home Pay Karyawan CV Saga Retailindo Sorong Tahun 2015

\begin{tabular}{|l|ll|r|lr|}
\hline \multicolumn{1}{|c|}{ Bagian } & \multicolumn{2}{c|}{$\begin{array}{c}\text { Take Home Pay } \\
\text { Karyawan }\end{array}$} & $\begin{array}{c}\text { Jumlah } \\
\text { Karyawan }\end{array}$ & \multicolumn{2}{c|}{ Take Home Pay } \\
\hline Administrasi & $\mathrm{Rp}$ & 47.002 .250 & 1 & $\mathrm{Rp}$ & 47.002 .250 \\
\hline Administrasi Gudang & $\mathrm{Rp}$ & 36.613 .500 & 4 & $\mathrm{Rp}$ & 146.454 .000 \\
\hline Ass. Administrasi & $\mathrm{Rp}$ & 28.404 .650 & 1 & $\mathrm{Rp}$ & 28.404 .650 \\
\hline CS & $\mathrm{Rp}$ & 40.108 .500 & 2 & $\mathrm{Rp}$ & 80.217 .000 \\
\hline IT & $\mathrm{Rp}$ & 56.443 .500 & 1 & $\mathrm{Rp}$ & 56.443 .500 \\
\hline Karyawan Gudang & $\mathrm{Rp}$ & 47.011 .962 & 13 & $\mathrm{Rp}$ & 611.155 .500 \\
\hline Kasir & $\mathrm{Rp}$ & 35.169 .150 & 22 & $\mathrm{Rp}$ & 773.721 .300 \\
\hline Kepala Counter & $\mathrm{Rp}$ & 38.952 .050 & 3 & $\mathrm{Rp}$ & 116.856 .150 \\
\hline Kepala Kasir & $\mathrm{Rp}$ & 37.753 .500 & 2 & $\mathrm{Rp}$ & 75.507 .000 \\
\hline Pramuniaga & $\mathrm{Rp}$ & 34.269 .150 & 156 & $\mathrm{Rp}$ & 5.345 .987 .400 \\
\hline Satpam & $\mathrm{Rp}$ & 51.823 .500 & 5 & $\mathrm{Rp}$ & 259.117 .500 \\
\hline Staff & $\mathrm{Rp}$ & 56.154 .214 & 14 & $\mathrm{Rp}$ & 786.159 .000 \\
\hline Supir & $\mathrm{Rp}$ & 41.247 .413 & 4 & $\mathrm{Rp}$ & 164.989 .650 \\
\hline Teknisi & $\mathrm{Rp}$ & 41.358 .825 & 4 & $\mathrm{Rp}$ & 165.435 .300 \\
\hline & $\mathrm{Rp}$ & $\mathbf{5 9 2 . 3 1 2 . 1 6 3}$ & $\mathbf{2 3 2}$ & $\mathrm{Rp}$ & $\mathbf{8 . 6 5 7 . 4 5 0 . 2 0 0}$ \\
\hline
\end{tabular}

Sumber: CV Saga Retailindo Sorong 
Saat perusahaan melakukan pemotongan $\mathrm{PPh}$ Pasal 21 maka timbul utang kepada pemerintah sampai dilakukan penyetoran ke kas negara. Berdasarkan perhitungan PPh Pasal 21 yang dilakukan oleh perusahaan maka pemotongan PPh Pasal 21 untuk tahun 2014 sebesar Rp 119.378.910 dan untuk tahun 2015 sebesar Rp 24.663.600. Perusahaan dalam membuat jurnal akuntansi terkait dengan penyetoran PPh Pasal 21 terutang karyawan yaitu:

1. Penyetoran PPh Pasal 21 yang terutang untuk bulan Januari sampai dengan bulan Desember tahun 2014

$\mathrm{PPh}$ Pasal 21 terutang $\quad \mathrm{Rp} \quad 119.378 .910$

$$
\text { Kas Rp } 119.378 .910
$$

2. Penyetoran PPh Pasal 21 yang terutang untuk bulan Januari sampai dengan bulan Desember tahun 2015

$$
\begin{gathered}
\text { PPh Pasal } 21 \text { terutang } \quad \text { Rp 24.663.600 } \\
\text { Kas }
\end{gathered}
$$

Namun berdasarkan perhitungan $\mathrm{PPh}$ Pasal 21 karyawan menurut peraturan perpajakan terdapat selisih lebih bayar sebesar Rp 6.374.160 untuk tahun 2014 dan selisih lebih bayar sebesar Rp 2.556.400 untuk tahun

1. Untuk tahun 2014

$$
\begin{array}{lll}
\text { Kas Utang Gaji } & &
\end{array}
$$

2. Untuk tahun 2015

$$
\text { Kas Utang Gaji }
$$

$$
\mathrm{Rp}
$$

\section{Kesimpulan dan Saran}

\subsection{Kesimpulan}

Berdasarkan hasil analisis data dan pembahasan yang penulis kemukakan diatas, maka penulis dapat mengambil kesimpulan sebagai berikut:

1. Perhitungan PPh Pasal 21 karyawan yang dilakukan oleh perusahaan belum sesuai dengan ketentuan peraturan perpajakan yang berlaku. Hal tersebut disebabkan karena perusahaan dalam menetapkan jumlah biaya jabatan bagi karyawan ditetapkan dengan jumlah yang sama untuk setiap karyawan yaitu untuk tahun 2014 sebesar Rp 1.300.000 dan tahun 2015 sebesar Rp 1.500.000. seharusnya perusahaan mengacu pada Peraturan Dirjen Pajak No.PER-32/PJ/2015 dimana biaya jabatan ditetapkan sebesar $5 \%$ dari penghasilan bruto setinggi-tingginya $\mathrm{Rp}$ 500.000 sebulan dan Rp 6.000 .000 setahun.
Rp 24.663.600

2015, maka jika perusahaan melakukan restitusi (pengembalian kelebihan pembayaran pajak kepada karyawan) maka jurnal koreksi yang harus dibuat perusahaan yaitu:

$\mathrm{Rp} \quad 6.374 .160$

$\mathrm{Rp} \quad 2.556 .400$

2. Terdapat perbedaan jumlah perhitungan PPh Pasal 21 karyawan menurut perhitungan perusahaan dan menurut peraturan perpajakan sehingga menyebabkan selisih lebih bayar sebesar Rp 6.374.160 untuk tahun 2014 dan sebesar Rp 2.556.400 untuk tahun 2015 .

3. Dalam menentukan penghasilan bruto, perusahaan telah menggunakan semua dasar penghasilan yang berupa gaji pokok, lembur, tunjangan tetap, tunjangan hari raya serta premi yang dibayar perusahaan terkait program BPJS Ketenagakerjaan dan BPJS Kesehatan berupa premi Jaminan Kecelakaan Kerja, Premi Jaminan Kematian dan Premi Askes yang dibayar perusahaan. Dalam hal komponen biaya yang menjadi pengurang penghasilan bruto diantaranya yaitu iuran Jaminan Hari Tua dan iuran Jaminan Pensiun yang dibayar karyawan telah sesuai dengan peraturan yang berlaku.

4. Dalam menentukan Penghasilan Tidak Kena Pajak, perusahaan telah mengacu 
pada Peraturan Menteri Keuangan No.162/PMK.011/2012 tentang penyesuaian besarnya Penghasilan Tidak Kena Pajak untuk tahun pajak 2014 dan Peraturan Menteri Keuangan No.122/PMK.010/2015 tentang penyesuaian besarnya Penghasilan Tidak Kena Pajak untuk tahun pajak 2015.

5. Perhitungan take home pay karyawan yang dilakukan perusahaan dihitung menggunakan dasar seluruh penghasilan yaitu gaji pokok, lembur, tunjangan tetap dan tunjangan hari raya kemudian dikurangi dengan iuran yang dibayar karyawan terkait program BPJS Ketenagakerjaan dan BPJS Kesehatan yaitu iuran Jaminan Hari Tua, iuran Jaminan Pensiun dan iuran Askes serta PPh Pasal 21 terutang karyawan.

\subsection{Saran}

Berdasarkan pembahasan dalam babbab sebelumnya, maka saran yang penulis kemukakan yaitu:

1. Bagi CV Saga Retailindo Sorong

a. Diharapkan untuk kedepannya perusahaan dalam menghitung PPh Pasal 21 karyawan benar-benar mengacu pada peraturan perpajakan yang berlaku.

b. Untuk meningkatkan kepatuhan terhadap peraturan perpajakan dan terus memperhatikan informasi terbaru yang berkaitan dengan perubahan-perubahan yang diberlakukan oleh Menteri Keuangan maupun Direktorat Jenderal Pajak.

c. Bagian administrasi perusahaan diharapkan dapat melampirkan perhitungan $\mathrm{PPh}$ Pasal 21 karyawan bersamaan dengan slip gaji karyawan sehingga karyawan lebih memahami cara perhitungan pajaknya.

d. Perusahaan dapat bekerja sama dengan Kantor Pelayanan Pajak (KPP) untuk mengadakan penyuluhan agar karyawan lebih mengetahui dan paham tentang cara perhitungan, pemotongan, dan pelaporan PPh Pasal 21 yang sesuai dengan peraturan perpajakan.

2. Bagi peneliti selanjutnya

a. Untuk peneliti selanjutnya diharapkan dapat menganalisa sampai pada permasalahan penyetoran dan pelaporan
PPh Pasal 21 sehingga dapat mengetahui apakah mekanisme perhitungan, pemotongan, penyetoran dan pelaporan PPh Pasal 21 telah sesuai dengan peraturan perundang-undangan yang berlaku.

\section{DAFTAR PUSTAKA}

Budi, H. Prianto. (2013). Manajemen Pajak. Jakarta: PT Pratama Indomitra Konsultan.

Charles E. Mclure, Jr. “Taxation”. Britannica, "Pajak - Wikipedia Bahasa Indonesia, ensiklopedia bebas", https://id.m.wikipedia.org/wiki/pajak diakses pada 13 Juni 2016

Forethought. 2013. Mudah Menghitung dan Melaporkan Pemotongan Pajak Karyawan SPT Masa PPh Pasal 21 dan/atau 26. Yogyakarta: Penerbit Andi.

Mardiasmo. (2000). Perpajakan. Edisi Revisi 2000. Yogyakarta: Penerbit Andi.

Meliala, Tulis S. \& Francisca. (2010). Perpajakan dan Akuntansi Pajak. Edisi 6. Jakarta: Penerbit Semesta Media.

MT Tax - Konsultan Pajak. (2014, 18 Desember). "Cara Menghitung Tunjangan PPh'dengan'Metode'Gross'Up', https://konsultanpajakblog.wordpress.co m/tag/menghitung-pph-21-gross-up/ diakses pada 1 Juli 2016

Nugroho, Suryo D. A. (2009). Cara Mudah Menghitung Pajak Pribadi. Jakarta: Penerbit Raih Asa Sukses.

Peraturan Direktur Jenderal Pajak No. PER32/PJ/2015 Tentang Pedoman Teknis Tata Cara Pemotongan, Penyetoran, dan Pelaporan Pajak Penghasilan Pasal 21 dan/atau Pajak Penghasilan Pasal 26 Sehubungan Dengan Pekerjaan, Jasa, dan Kegiatan Orang Pribadi.

Peraturan Lengkap Pajak Penghasilan, Fokusmedia, Bandung, 2009

$\begin{array}{ccr}\text { Peraturan } & \text { Menteri } & \text { Keuangan } \\ \text { No.162/PMK } 011 / 2012 & \text { Tentang }\end{array}$ Penyesuaian Besarnya Penghasilan Tidak Kena Pajak

Peraturan Menteri Keuangan No.122/PMK.010/2015 Tentang Penyesuaian Besarnya Penghasilan Tidak Kena Pajak. 
Peraturan Menteri Keuangan

No.101/PMK.010/2016 Tentang

Penyesuaian Besarnya Penghasilan Tidak

Kena Pajak

Setiawan, Hendy. (2013, 28 Juli). "Metode

Pemotongan PPh Pasal 21 Mixed sebagai alternatif berbagi beban",

http://www.ortax.org/ortax/?mod\%3Diss

ue\%26page\%3Dshow\%26id\%3D52\&ei=

sDkImlFL\&lc=id-

ID\&s=1\&m=812\&host=www.google.co. id\&ts=1468766124\&sig=AKOVD67Gnz

ByDuHEp5 SR ecN36TvuG5IQ diakses pada 17 Juli 2016.

Undang-Undang Republik Indonesia Nomor 6 Tahun 1983 tentang Ketentuan Umum dan Tata Cara Perpajakan sebagaimana telah diubah terakhir dengan UndangUndang Republik Indonesia Nomor 16 Tahun 2009.

Undang-Undang Republik Indonesia Nomor 36 tahun 2008 tentang Perubahan Keempat Atas Undang-Undang Nomor 7 Tahun 1983 Tentang Pajak Penghasilan. Waluyo. (2014). Akuntansi Pajak. Edisi 5. Jakarta: Penerbit Salemba Empat.

www.pajak.go.id 